\title{
VDR Gene
}

National Cancer Institute

\section{Source}

National Cancer Institute. VDR Gene. NCI Thesaurus. Code C18503.

This gene plays a role in transcriptional regulation and in vitamin D3 metabolism. 